\title{
Ornithogenic vegetation: How significant has the seabird influence been on the Aleutian Island vegetation during the Holocene?
}

\author{
Olesya Igorevna Smyshlyaeva $^{1}$ (D) | Elena Erastovna Severova ${ }^{2,3}$ | \\ Olga Aleksandrovna Krylovich ${ }^{1}$ | Evgeniya Andreevna Kuzmicheva ${ }^{1}$ | \\ Arkady Borisovich Savinetsky $^{1}$ | West Dixie ${ }^{4}$ | Virginia Hatfield ${ }^{5}$
}

\author{
${ }^{1}$ Laboratory of Historical Ecology, Severtsov \\ Institute of Ecology and Evolution, Russian \\ Academy of Sciences, Moscow, Russia \\ ${ }^{2}$ Biology Faculty, Department of Higher \\ Plants, Lomonosov Moscow State \\ University, Moscow, Russia \\ ${ }^{3}$ Faculty of Biology and Biotechnologies, \\ National Research University Higher School \\ of Economics, Moscow, Russia \\ ${ }^{4}$ Biodiversity Institute, University of Kansas, \\ Lawrence, KS, USA \\ ${ }^{5}$ Museum of the Aleutians, Unalaska, AK, \\ USA

\section{Correspondence} \\ Olesya Igorevna Smyshlyaeva, Laboratory \\ of Historical Ecology, Severtsov Institute of \\ Ecology and Evolution, Russian Academy of \\ Sciences, Leninsky pr. 33, 119071, Moscow, \\ Russia. \\ Email: smyslyaevaol@gmail.com

\section{Funding information} \\ Russian Foundation for Basic Research \\ \#19-34-90071, National Geographic \\ Society (\#4943-92, \#5252-94), National \\ Science Foundation (OPP-93 14472) and \\ supplementary grant from National Science \\ Foundation (OPP-96 14472)
}

\begin{abstract}
In the Aleutian Islands during the Holocene, terrestrial predators were actually absent; as a result, large seabird colonies thrived along the coasts or across entire islands. Bird guano enriches the soil with nitrogen, which can lead to the formation of highly modified ornithogenic (bird-formed) ecosystems. For a more detailed investigation of avian influence, we reconstructed more than 10,000-year-old vegetation dynamics of the coast of Shemya Island (Near Islands) by pollen analysis. At the initial stages of vegetation development (10,000-4,600 cal year BP), sedge-heather tundra grew in the studied area. A seabird colony existed on Shemya from 4,600 to 2,400 cal year BP according to stable isotope analysis. During a period of at least 2,200 years, nitrogen enrichment led to the development of ornithogenic herb meadows with a high presence of Apiaceae. A long-term increase in $\delta 15 \mathrm{~N}$ above $9-10 \%$ led to radical shifts in vegetation. Noticeable reduction of seabird colonies due to human hunting led to grass-meadows spreading. After a prolonged decrease $\delta 15 \mathrm{~N}$ below $9-10 \%$ (2,400 cal year BP to present), there was a shift toward less productive sedge-tundra communities. However, the significant enrichment of guano affected only the coastal vegetation and did not alter the inland Shemya Island.
\end{abstract}

KEYWORDS

Aleutian Islands, islands ecosystems, pollen analysis, seabird guano, vegetation dynamics

\section{1 | INTRODUCTION}

Vegetation history on the oceanic islands is one of the crucial points of island ecology. Plant community dynamics can be affected by a variety of factors; changing climatic conditions is one of most important (Bennett et al., 1997; Bunting, 1994; Lawson et al., 2005; Molloy \& O'Connell, 2004; Weigelt et al., 2016). Besides climate, there are a lot of other drivers as well as altitude, area and geological age of islands, soils, oceanic flows, isolation, volcanic activity, human activity, etc. (Garroutte et al., 2018; Heusser, 1990; Lawson

This is an open access article under the terms of the Creative Commons Attribution License, which permits use, distribution and reproduction in any medium, provided the original work is properly cited.

(c) 2021 The Authors. Ecology and Evolution published by John Wiley \& Sons Ltd. 
et al., 2008; McCord, 1980). According to their geography and geology, the Aleutian Islands serve as a model for observing the vegetation history during the Holocene.

The Aleutian Islands are a volcanic origin archipelago extending almost 2,000 km from Kamchatka to mainland Alaska. The fundamental climatic patterns of the Aleutian Islands are determined by the position of the Aleutian Low (Broadman et al., 2020; Rodionov et al., 2005, 2007). Mild winters, high humidity, cloudiness, fogs, frequent storms, and strong winds are the features that define the Aleutian landscape (Hultén, 1968). The proximity of Kamchatka to the west of the Aleutian arc and Alaska to the east also enhances the difference in the flora and vegetation between the western and eastern islands (Garroutte et al., 2018; Garroutte \& IckertBond, 2013; Hulten, 1937). There are only 520 vascular plant species across the arc, and species richness of plant communities is less than in the same communities on the mainland; therefore, these ecosystems are very sensitive to various disturbances (Garroutte, 2018). According to vegetation studies, the plant communities also depend on altitude, drainage, and soil properties (Byrd, 1984; Hulten, 1968; Talbot et al., 2010; Talbot \& Talbot, 1994). Another important factor is the snow distribution in winter, which is determined by the wind strength and topography (Hultén, 1937, 1968). At the same time, the islands are located practically at the same latitude, which is why they are unique model objects for studying the interaction and influence of all the above driving forces.

Regional flora and vegetation were formed mainly in the Holocene (Garroutte et al., 2018; Hulten, 1968). Among more than 200 Aleutian Islands, the Holocene vegetation dynamics have been reconstructed on Attu (Heusser, 1990), Tanaga (Anderson \& Bank, 1952), Adak (Heusser, 1978; Noguchi et al., 2018), Atka (Heusser, 1990), Carlisle (Kuzmicheva et al., 2019), Umnak (Heusser, 1973), and Unalaska (Anderson \& Bank, 1952). In these studies, climate was considered as the main factor affecting vegetation, but it was difficult to identify the general pattern of plant communities changing. The most noticeable shifts were in dominance between herbaceous taxa and dwarf shrub or between sedges and grasses as a result of changes in temperature and/or moisture. However, along the entire archipelago, the shifts happened asynchronously and occasionally did not coincide with the main climatic phases. These inconsistencies, among other things, are also associated with strong volcanic activity in this region. Eruptions and ash falls are the second most important factor determining the landscape and vegetation of the Aleutian Islands in the Holocene (Heusser, 1990; Kuzmicheva et al., 2019; Noguchi et al., 2018). As a result of eruptions, plant communities are sometimes completely disrupted, and their formation begins anew (Talbot et al., 2010). Ashes alter the chemical composition of soils, which also affects ecosystems (Kuzmicheva et al., 2019). Nevertheless, it also remains unknown how exactly volcanic activity influenced vegetation over long-term timescales.

When reconstructing the dynamics of Aleutian Islands plant communities, researchers focused on the above two factors (Heusser, 1973, 1978, 1990; Kuzmicheva et al., 2019; Noguchi et al., 2018). Seabird activity as an important factor remains insufficiently studied. The Aleutian Islands are remarkable because there were predominantly no terrestrial predators east of the Commander Islands and west of Umnak prior to the start of their human colonization in 1741 (Crockford, 2012; Maron et al., 2006; West et al., 2007). Due to this, billions of birds have formed large colonies on the Aleutian Islands over thousands of years (Byrd, Day\&, 1986; Crockford, 2012; Croll et al., 2005; Krylovich et al., 2019; Maron et al., 2006). According to botanical investigations on other North Pacific Islands, even short-term impact of seabird colonies lead to changes in vegetation cover, and in the soil chemistry or bedrock and eventually to the formation of ornithogenic ecosystems and vegetation (Ivanov, 2013). The long-term effects of birds and dynamics of their colonies during the Holocene have been studied in Greenland and Svalbard by the stable isotope analysis of lake sediments and peat cores (Davidson et al., 2018; Gąsiorowski \& Sienkiewicz, 2019; Yuan et al., 2010). Seabirds provide large amounts of marine organic matter to nutrient-limited terrestrial ecosystems by guano (Caut et al., 2012; Maron et al., 2006), which is reflected in the sediments by the enrichment of the heavy nitrogen isotope, namely significant increase of $\delta^{15} \mathrm{~N}$ value (Croll et al., 2005; Davidson et al., 2018; Gąsiorowski \& Sienkiewicz, 2019; Maron et al., 2006; Szpak et al., 2012; Yuan et al., 2010). We hypothesized that for Aleutian Islands plant communities depleted by abundant rainfalls and intense leaching, this fertilization has a significant impact. However, it remains unknown whether vegetation changes under the influence of millennial-scale dynamics of seabird colonies.

At the same time, in the Aleutian Islands, relatively short declines in seabird impact on ecosystems have already been studied. On islands, where Arctic foxes (Vulpes lagopus) have been introduced since the 18th century, plant communities have changed from highly productive grasslands to dwarf shrub-dominated ecosystems (Croll et al., 2005; Maron et al., 2006). There was a significant difference in the $\delta^{15} \mathrm{~N}$ values of soils and plants between fox-free and fox-infested islands, although this distinction could vary greatly depending on the island size and the distance from the coast. The $\delta 15 \mathrm{~N}$ value increased up to $14 \%$ in soils and almost $16 \%$ in grasses on the fox-free islands (Maron et al., 2006). Based on these results, the guano influence on the coastal ecosystem of Carlisle Island (Islands of Four Mountains, Aleutian Islands) during the Holocene was found by the isotopic signature (Kuzmicheva et al., 2019). However, noticeable shifts in vegetation were not detected due to the earlier peopling of the eastern part of the Aleutian Islands, the short-term impact, and many ash layers in the peat core (Kuzmicheva et al., 2019). Higher $\delta 15 \mathrm{~N}$ values over a longer period of time were found in an ash-free coastal peat deposit on Shemya Island, one of the westernmost islands of the archipelago (Savinetsky et al., 2014). Compared to the inland peat core of this island, the values of the heavy nitrogen isotope were several times higher during most of the Holocene (Savinetsky et al., 2010, 2014). According to archaeological data, the first settlements appeared on Shemya Island about 3,000 cal year BP, which coincides with the time when the $\delta 15 \mathrm{~N}$ value in the coastal deposit decreased (Lefevre et al., 2010; Savinetsky et al., 2014). The existence and subsequent significant reduction of the colony is also 
confirmed by zooarchaeological discoveries in archaeological sites (Lefèvre et al., 2010). We hypothesized that, in contrast to the inner vegetation (Smyshlyaeva et al., 2021), the coastal one reflected not only climate impact but also the considerable seabird nutrient input.

To study the seabird impact on Aleutian Islands plant communities, we reconstructed vegetation dynamics recovered from the coastal peat deposit (McDonald Point) on Shemya Island using pollen analysis. We investigated the composition of this profile by radiocarbon dating, age-depth model and estimation of sediment rate, and loss-of-ignition (LOI) to more accurately interpret vegetation history. In this paper, we answer two questions: Do long periods of intensive seabird impact affect coastal Aleutian Island vegetation? And how do plant communities change after reduction of these impacts?

\section{2 | MATERIALS AND METHODS}

\section{1 | Sampling}

Shemya is a flat island, devoid of volcanoes, located at $52^{\circ} \mathrm{N}$ and $174^{\circ} \mathrm{E}$. It is approximately $4.5 \mathrm{~km}$ wide by $7 \mathrm{~km}$ long with a total area of $15 \mathrm{~km}^{2}$ (Figure 1). The island relief is gently hilly. The vegetation is represented by two types of communities, with herbaceous plant and dwarf shrub dominant (Causey et al., 2010; Kiseleva et al., 2002; Savinetsky et al., 2014). Grasses and sedges, along with a noticeable abundance of forbs, dominate the stream valleys, lowlands, and slopes of different exposures. These communities are more diverse on well-drained southern slopes. Meadow vegetation dominated by Leymus mollis, Heracleum lanatum, and Senecio pseudo-arnica occurs on hills near the sea coast (Savinetsky et al., 2010). Sedges often become dominant under waterlogged conditions (Causey et al., 2010; Kiseleva et al., 2002). The second type of community is dominated by dwarf shrubs (Empetrum nigrum, Vaccinium vitis-idea, Linnea borealis) and occurs on more exposed sites (Causey et al., 2010; Kiseleva et al., 2002).

A peat deposit was sampled at McDonald point on the east coast of Shemya Island in 1999 (Figure 1). The land surface was flat, slightly sloping, with a steep ledge protruding into the sea. The ledge was cut during quarrying and exposed the bedrock and peat profile. The depth of the sampled core was $385 \mathrm{~cm}$. We cleaned and smoothed out the exposure. Samples were taken into plastic bags by a trowel layer by layer; their thickness was on average $5 \mathrm{~cm}$, taking into account the sediment stratigraphy. The trowel was cleaned after each sample. All samples were taken to the laboratory and stored in a cold room.

\subsection{1 | Radiocarbon dating}

To determine the chronology and accumulation rate of the sediment, we selected all plant remains from 7 peat samples after acidalkaline-acid extraction for radiocarbon dating (Table 1). Dating was carried out by the scintillation method (Piotrowska et al., 2011) in the Laboratory of Historical Ecology of A.N. Severtsov Institute of

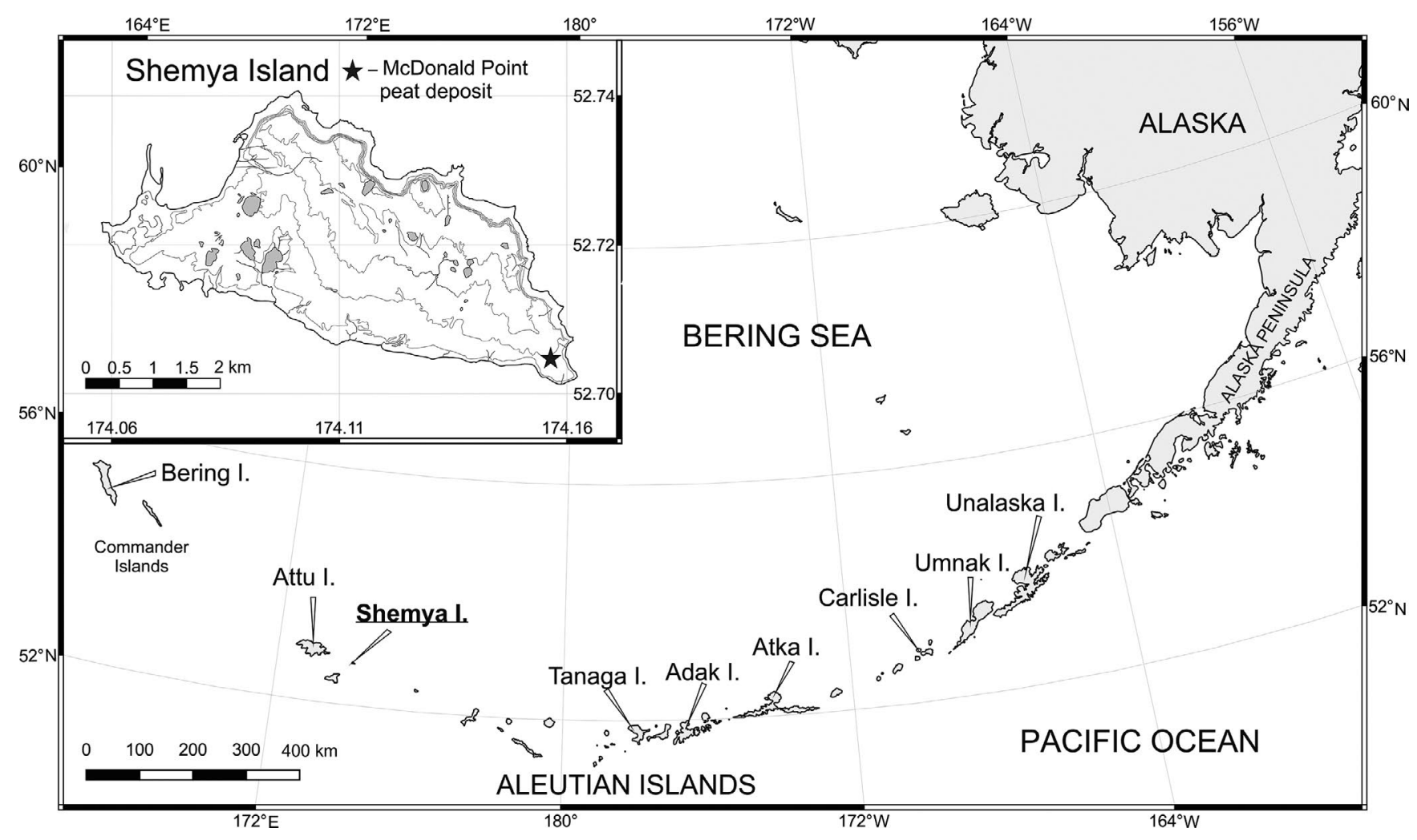

FIG URE 1 The study area map. The inset shows Shemya Island (the Near Islands) and the McDonald Point peat deposit (mark) 
TABLE $1{ }^{14} \mathrm{C}$ ages of McDonald Point peat deposit

\begin{tabular}{lclcl} 
Depth $(\mathrm{cm})$ & ${ }^{14}$ C age (year BP) & $\begin{array}{l}\text { Age range (cal year } \\
\text { BP) } 2 \sigma\end{array}$ & $\begin{array}{l}\text { Median age (cal } \\
\text { year BP) }\end{array}$ & Lab ID \\
\hline $50-55$ & $400 \pm 100$ & $614-159$ & 425 & IEMAE-1243 \\
\hline $80-85$ & $875 \pm 65$ & $918-692$ & 796 & IEMAE-1285 \\
\hline $125-130$ & $1,405 \pm 100$ & $1520-1094$ & 1,323 & IEMAE-1280 \\
\hline $225-230$ & $3,295 \pm 90$ & $3772-3343$ & 3,528 & IEMAE-1279 \\
\hline $265-270$ & $4,060 \pm 80$ & $4811-4326$ & 4,569 & IEMAE-1262 \\
\hline $318-320$ & $6,430 \pm 155$ & $7580-6977$ & 7,335 & IEMAE-1286 \\
\hline $363-372$ & $9,550 \pm 130$ & $11185-10504$ & 10,879 & IEMAE-1261 \\
\hline
\end{tabular}

Ecology and Evolution of Russian Academy of Sciences. Radiocarbon dates were calibrated to determine calendar ages and to frame the age-depth model (Figure 2) by the "IntCal13" ground calibration curve (Reimer et al., 2013). We carried out these calculations and sedimentation rate in the package "Bchron" 4.2.6 (Haslett \& Parnell, 2008; Parnell, 2015) in the statistical environment R v. 3.6.2 ( $R$ Core Team, 2019). Calibrated dates are given in the text below.

\subsection{2 | Loss-of-ignition}

To determine organic content dynamics, a total of 65 samples were placed in the crucible and then in the muffle furnace at $550^{\circ} \mathrm{C}$ for at least $2 \mathrm{hr}$ for measuring organic content. To calculate LOI values, we subtracted weight after ashing from the dry weight and expressed it as \% (Chambers et al., 2010).

\subsection{3 | Pollen analysis}

To reconstruct vegetation dynamics, a total of 66 samples $2-4 \mathrm{~cm}^{3}$ in size with an interval of 5-10 cm were selected for pollen analysis. We used boiling in $10 \% \mathrm{HCl}, 10 \% \mathrm{KOH}$, washing through a sieve
(250 $\mu$ ), boiling in HF, acetolysis, according to the standard procedure with some modifications for chemical processing of samples (Chambers et al., 2011; Faegri \& Iversen, 1975). To determine the concentration of pollen and spores, the special markers were added before chemical treatment (Stockmarr, 1973). We added two tablets of Lycopodium clavatum spores from batches \#483216 or \#938934 to each sample. Pollen atlases and keys (Reille, 1998, 1999), electronic databases (https://globalpollenproject.org), and a reference collection (Severova et al., 2016; http://botany-collection.bio.msu. ru) were used to determine pollen and spores taxa.

Using an Axioskop ZEISS light microscope with a magnification of $\times 400$, we counted pollen up to at least 500 pollen grains in those samples, where possible. The percentage of pollen types was calculated from the total of all pollen in the sample, and the percentage of spores from the total of pollen and spores. Total pollen influx was calculated by multiplying the total pollen concentration and sedimentation rate of each sample (Hicks \& Hyvärinen, 1999). Tilia software v.2.0.41 was used to construct pollen diagrams (Grimm, 2015). Percentage and concentration diagrams are presented in abbreviated form; taxa that occur singly are excluded. Complete diagrams and spreadsheets are available in the Data Accessibility Statement. We identified pollen zones by stratigraphically constrained cluster analysis (CONISS) (Grimm, 2015).
FIGURE 2 McDonald Point age-depth model. Dark gray-calibrated dates, gray-95\% chronology confidence interval

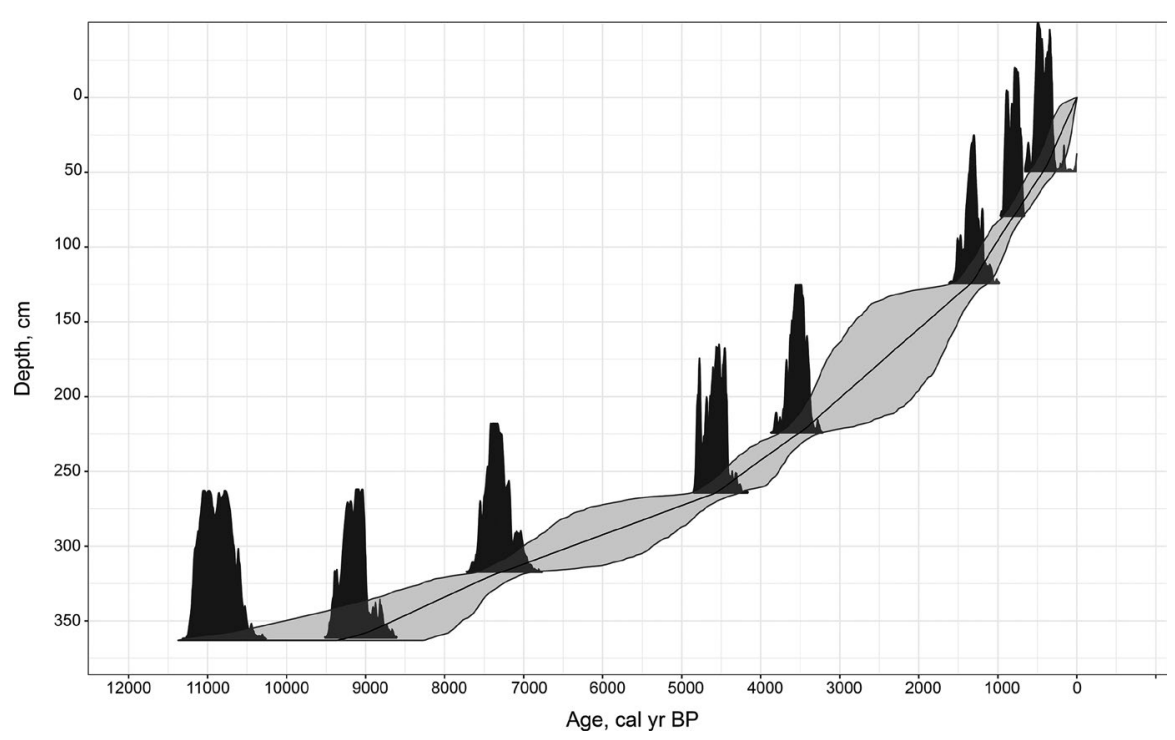




\section{3 | RESULTS}

The McDonald Point deposit began forming prior to 10,000 cal year $\mathrm{BP}$, as evidenced by the date for $363 \mathrm{~cm}$ (Figure 2, Table 1). The sedimentation rate gradually increased to the top of the core from 0.04 to $0.19 \mathrm{~cm} /$ year (Figure 2). The LOI was quite low and gradually declined from 10,000 to 5,600 cal year BP, the average was 30\%. From 4,750 to $3,750 \mathrm{cal}$ year BP, it gradually increased and then was relatively stable from 3,600 to 2,500 cal year BP, on average $85 \%$. Since 2,500 years ago, the LOI has fluctuated significantly again, averaging 30\% (Figures 3 and 4).

In the pollen spectra, we identified a total of 46 palynotypes: 7 arboreal taxa (we included Ericaceae in this group), 31 nonarboreal taxa, and 8 types of spores. This is comparable to recent pollen reconstructions on the Aleutian Islands (Kuzmicheva et al., 2019; Noguchi et al., 2018; Smyshlyaeva et al., 2021) and slightly more than in Heusser's (Heusser, 1973, 1978). The pollen concentration of arboreal taxa was on average 14,600 grains $/ \mathrm{cm}^{3}$, nonarboreal taxa on average 87,880 grains $/ \mathrm{cm}^{3}$ and spores on average 9,260 grains/ $\mathrm{cm}^{3}$. Total pollen influx was on average 6,750 grains $/ \mathrm{cm}^{2} /$ year, which corresponds to amounts in late Quaternary tundra on Atka peat deposit (Heusser, 1990) and other parts of Alaska (Anderson, 1988; Brubaker et al., 1983).

The dominant taxa are Cyperaceae, Apiaceae, Ericaceae, Poaceae, and Lycopodium annotinum (Figure 3). The total pollen concentration (TPC) was on average 104,700 grains $/ \mathrm{cm}^{3}$ (Figure 4), which is higher than the maximum TPC values for Carlisle Island (Kuzmicheva et al., 2019), and significantly higher than in peatlands of Arctic Coastal Plain of Alaska (Eisner et al., 2005).

We recognized 3 pollen zones: McDP-Z1 $(385-265 \mathrm{~cm}, 10,000-$ 4,600 cal year BP), McDP-Z2 (265-175 cm, 4,600-2,400 cal year $\mathrm{BP})$, and McDP-Z3 (175-0 cm, 2,400-0 cal year BP) (Figure 3). Application of CONISS to the pollen concentration data produced the same pollen zonation (Figure 4).

\section{1 | McDonald Point-1 (385-265 cm, 10,000- 4,600 cal year BP)}

Ericaceae-dominant tundra with a noticeable abundance of sedges occupied the main area of the island and then dwarf shrubs gradually decreased. Between 6,400 and 4,600 cal year BP, hearth-grasssedge tundra with a significant component of Lycopodium annotinum dominated along the coast.

The dominants in the spectra changed occasionally. Ericaceae and Cyperaceae pollen predominated at this zone, on average 35\% each other. The percentage of Lycopodium annotinum spores was the highest in this zone (up to 66\%). On average Apiaceae pollen abundance was $6 \%$, approximately $6,400 \mathrm{cal}$ year BP it started to increase gradually. Poaceae pollen abundance began to rise circa 6,200 cal year BP. Pollen influx was on average 4,450 grains $/ \mathrm{cm}^{2} /$ year.

\section{2 | McDonald Point-2 (265-175 cm, 4,600- 2,400 cal year BP)}

The pollen spectra changed dramatically 4,600 cal year BP, when meadows with the highest levels of Apiaceae emerged. Grasslands began to spread around 3,000 cal year BP.

Apiaceae pollen dominated in this zone (up to $85 \%$ ). Poaceae pollen reached its maximum in the upper part of this zone. Ericaceae pollen percentage and concentration dropped dramatically. In the interval 3,000-2,400 cal year BP (205-175 cm), Poaceae pollen together with Apiaceae dominated, $38 \%$ and $46 \%$ on average, respectively. Pollen influx was on average 10,330 grains $/ \mathrm{cm}^{2} /$ year in this zone.

\section{3 | McDonald Point-3 $(175-0 \mathrm{~cm}, 2,400-0$ cal year $\mathrm{BP})$}

After a sharp decrease in Poaceae percentage, sedge tundra with some grasses, umbelliferous, and ferns spread on the coast of Shemya Island. Lycopodium and dwarf shrubs rarely occurred in these communities.

The Cyperaceae pollen dominated in this zone (on average 69\%). Poaceae and Apiaceae pollen percentages were significantly reduced in comparison with the previous zone, $8 \%$ and $10 \%$ on average. Pollen influx was on average 6,080 grains $/ \mathrm{cm}^{2} /$ year.

\section{4 | DISCUSSION}

We reconstructed the history of coastal vegetation formation on Shemya Island during almost ten thousand years by comparing new pollen analysis and LOI results with the radiocarbon and stable isotopes data from (Savinetsky et al., 2014). In the early stages of coastal vegetation formation (up to 9,100 cal year BP), dwarf shrub communities were widespread near the McDonald Point peat deposit. In general, heathers (Ericaceae) are a common component of a subarctic island's vegetation in an oceanic climate (Charman, 1994). Dwarf shrub communities dominated by crowberry (Empetrum) occurred on well-drained slopes up to the vegetation border and in the lowlands open to winds in the Aleutian Islands and on the Alaska Peninsula (Heusser, 1978, 1983; Jordan \& Krumhardt, 2003). In the Alpine lands, grasses and sedges dominate together with crowberry, and Lycopodium dominates with Empetrum in the open lowlands (Heusser, 1978). Heusser (1990) highlighted that in the pollen spectra, heathers are an important indicator of habitats which are exposed to strong wind, which has also been noted for Ericaceae in other regions (Breslina, 1987). However, the climate was warm and humid at the Early Holocene (Peteet et al., 2019), which was reflected in the fact that wet sedge tundra predominated in the Shemya interior (Smyshlyaeva et al., 2021) unlike the coastal vegetation with dwarf shrubs (Figures 3 and 4). Island interior was similar to the primary herbaceous vegetation at Atka and Umnak, 


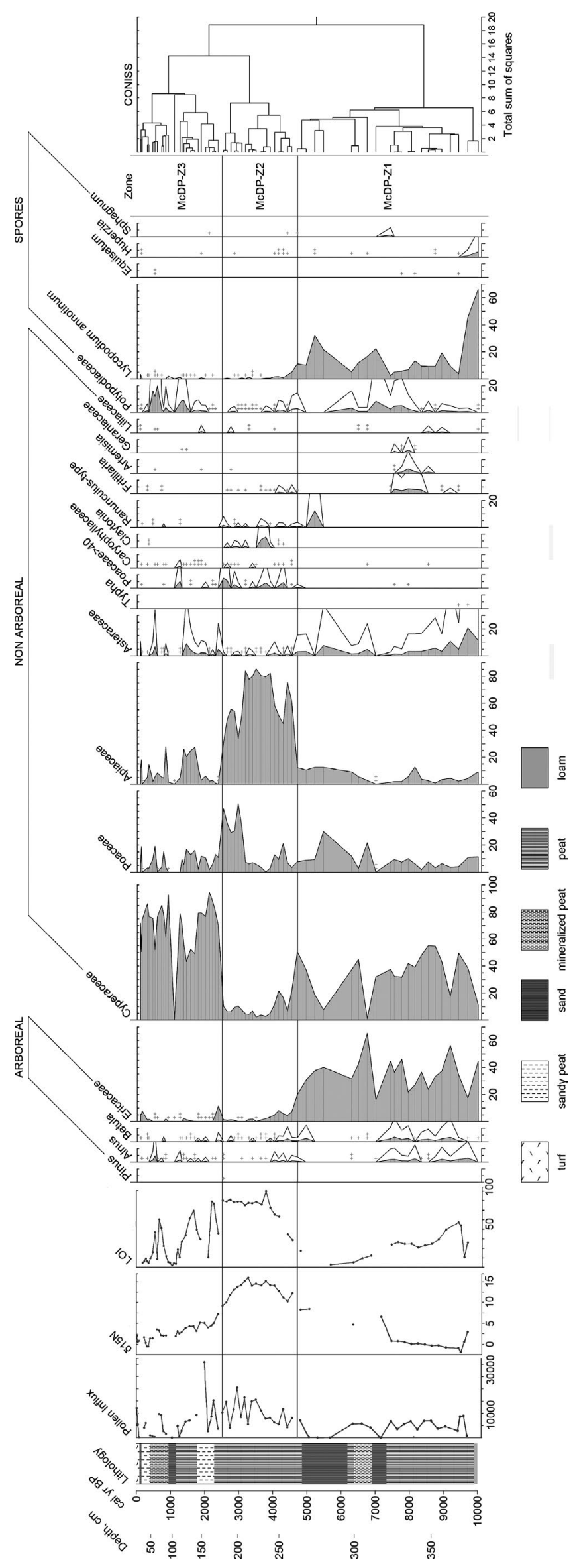

FIGURE 3 Abbreviated pollen percentage diagram for McDonald Point peat deposit. White curves exaggerated $x 5$. McDP-Z1, McDP-Z2, McDP-Z3 pollen zones identified on the basis of CONISS are shown by solid lines. Signs + and ++ mark single pollen grains. The full diagram is presented in the Data Accessibility Statement. LOI values are presented in \%. Pollen influx is presented in grains $/ \mathrm{cm}^{2} /$ years. $\Delta 15 \mathrm{~N}$ values given from Savinetsky et al. (2014) in \%. Some more samples were added by the same methodology to reduce the previous gaps

where the peat profiles were sampled in more sheltered habitats (Heusser, 1973, 1990). Thus, in this study, we have the opportunity to reconstruct vegetation history especially on the coast, not just the entire island or the whole region.

Diatom analysis indicates that relatively deep fresh water existed nearby McDonald Point during the initial stages of peat formation (Neplukhina et al., 2018). However, we only found single Typha pollen and Equisetum spores in the lowest pollen assemblages (Figures 3 and 4). These taxa are indicators of open water bodies (Galka et al., 2018), but their presence was too insignificant to indicate waterlogged vegetation in the McDonald Point pollen spectra.

The discovery of Betula, Alnus, and Pinus pollen can be attributed to the long-distance air mass transport from Kamchatka (Heusser, 1990; Noguchi et al., 2018). Thus, we did not consider their variation in the reconstruction of the Aleutian Islands vegetation.

About 9,100 cal year BP, the coastal environment became relatively stable. In general, heather-sedge tundra dominated (Figure 3). The combination of Poaceae, Cyperaceae, and Empetrum in the vegetation composition is also typical for the coastal tundra of Alaska (Jordan \& Krumhardt, 2003) and other oceanic islands including Shetland, Faroe, Iceland, and the White Sea Islands (Breslina, 1987; Hulme \& Shirriffs, 1994; Lawson et al., 2008). There is evidence that at the Early and Early-Mid Holocene the temperature on the western islands was also colder than on the eastern ones, as in modern times, due to cold air masses from the northwest (Rodionov et al., 2007). However, even during the warmest periods of the Holocene, the sedge-tundra vegetation prevailed on the Shemya instead of meadows (Figures 3 and 4; Smyshlyaeva et al., 2021).

The relatively drier conditions in the eastern North Pacific circa 8,700 cal year BP (Peteet et al., 2019) were not reflected in noticeable changes in the pollen spectra of McDonald Point. However, the humidity on the western and eastern islands did not change synchronously, as proposed in modeling studies (Rodionov et al., 2005, 2007). The asynchrony of some atmospheric phases along the archipelago was revealed from short-term observation series, but there are no data on how exactly they were interrelated during the Holocene.

To detect detailed changes in the Shemya seashore environment, we compared results of pollen analysis with $\delta^{15} \mathrm{~N}$ values from the same peat profile (Savinetsky et al., 2014). For coastal ecosystems, an increase in this value means the transfer of organic matter from the sea to terrestrial communities (Anderson \& Polis, 1999; Caut et al., 2012; Croll et al., 2005; Maron et al., 2006; Szpak et al., 2012). Until 7,100 cal year BP, the $\delta^{15} \mathrm{~N}$ averaged $0.12 \%$, 


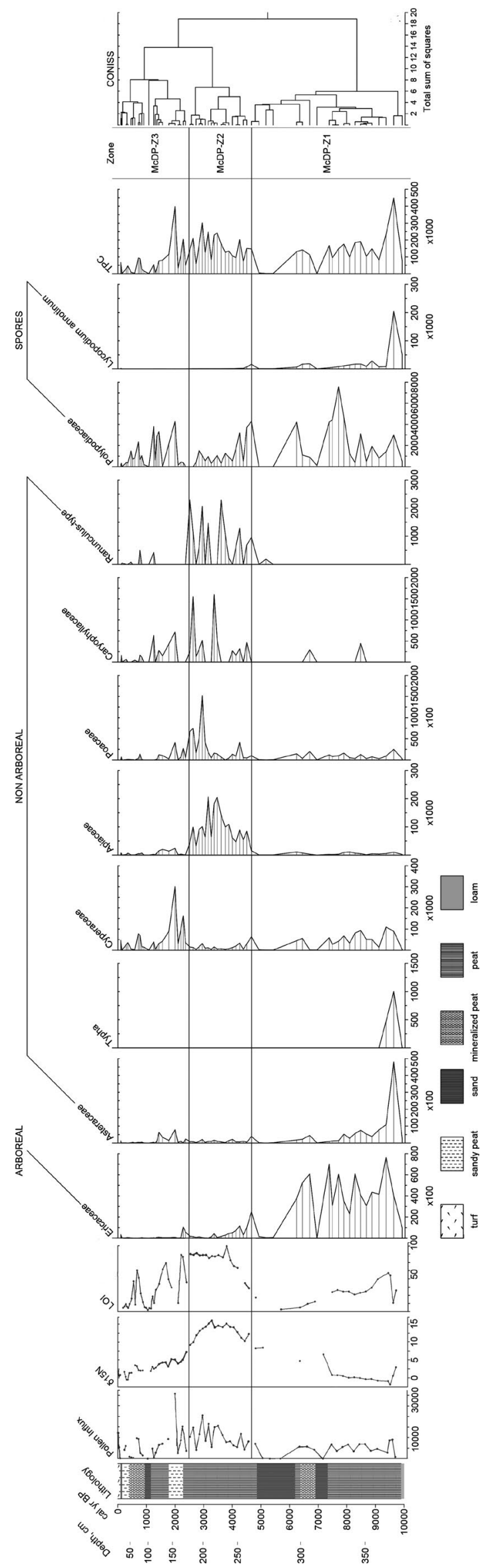

FIGURE 4 Abbreviated pollen concentration diagram for the McDonald Point peat deposit (grains/ $\mathrm{cm}^{3}$ ). McDP-Z1, McDP-Z2, McDP-Z3 pollen zones identified on the basis of CONISS are shown by solid lines. The full diagram is presented in the Data Accessibility Statement. LOI values are presented in \%. Pollen influx is presented in grains $/ \mathrm{cm}^{2} /$ years. $\Delta 15 \mathrm{~N}$ values given from Savinetsky et al. (2014) in \%. Some more samples were added by the same methodology to reduce the previous gaps

which is typical for arctic and subarctic peatlands (Croll et al., 2005; Davidson et al., 2018; Gąsiorowski \& Sienkiewicz, 2019). This value was also close to the values in the interior peat deposit on Shemya Island, which averaged $-0.78 \%$ over the same period of time (Savinetsky et al., 2014). The heavy nitrogen isotope abundance in the McDonald Point peat deposit increased significantly circa 7,100 cal year BP (up to $6.55 \%$ ), then about 6,300 cal year BP, it was $4.70 \%$, and from 5,000 cal year BP, it has steadily increased to $8.42 \%$ and above (Figures 3 and 4; Savinetsky et al., 2014). There are no $\delta^{15} \mathrm{~N}$ measures in the samples 7,100-6,300 cal year BP (310$300 \mathrm{~cm})$ and 6,300-5,000 cal year BP $(296-275 \mathrm{~cm})$ due to insignificant amount of organic matter at this part of the core, which is mainly sand or peaty sand (Figures 3 and 4). At this time, there was dry coastal shrub tundra around, and the LOI in the samples was the lowest (Figures 3 and 4). Drier conditions may be related to the next decrease in available moisture around 6,500 years ago (Peteet et al., 2019). However, it could also be due to abrupt changes in sea level, which was established at present altitude by 5,000 years ago (Black, 1980; Kiseleva et al., 2002). As a result of several significant shifts in the coastline, the McDonald Point deposit was covered with sand several times and the peat began to accumulate again, while $\delta^{15} \mathrm{~N}$ dynamics remained unknown.

About 4,600 cal year BP, the McDonald Point pollen spectra dramatically changed (Figures 3,4 ) from coastal tundra to meadow vegetation with the highest Apiaceae abundance. Higher copresence of Apiaceae and Poaceae in the spectra (Figures 3 and 4) indicates the typical coastal vegetation of the Aleutian Islands and Alaska (Hulten, 1968). These are tall grasses that do not occur on high slopes and places exposed to the wind (Garroutte \& IckertBond, 2013; Heusser, 1990). LOI also increased strongly as a result of the more plant biomass accumulation and/or a decreased degradation rate under lower temperature (Figures 3 and 4). The expansion of tall-grass meadows would rather take place in the Early Holocene, when the highest temperatures were observed (Peteet et al., 2019) or in the Holocene maximum 7,000-5,000 years ago (Kaufman et al., 2016). However, according to various estimates, circa 4,500 years ago and later, the early Neoglacial events began, which resulted in an increase in storm activity and a decrease in temperature throughout the Bering Sea region (Barclay et al., 2009; Broadman et al., 2020; Kaufman et al., 2016; Peteet et al., 2019). Therefore, it remains unknown what climatic shifts during the subsequent cooling period could lead to the replacement of coastal tundra with more productive meadow vegetation.

At the same time circa 4,600 cal year $\mathrm{BP}, \delta^{15} \mathrm{~N}$ increased significantly to $12.24 \%$ o in the coastal peat core (Figures 3,4 ). In the 
Arctic ecosystems, the usual nitrogen value does not exceed $3 \%$ (Janbu et al., 2011; Perren et al., 2012). In many studies devoted to the investigation of island ecosystems, the increment in the heavy nitrogen isotope content in various sediments and organisms is associated with the appearance of seabird colonies and guano fertilization of substrate (Croll et al., 2005; Maron et al., 2006; Szpak et al., 2012). (Caut et al., 2012; Spazk et al., 2012). Similar increases of several ppm are also shown in Svalbard and Greenland over long periods of time or even the entire Holocene (Davidson et al., 2018; Gąsiorowski \& Sienkiewicz, 2019; Yuan et al., 2010). In Alaska, fluctuations in the range of $2-3 \%$ are estimated for fluctuations in the number of sockeye salmon over the millennia, which also reflect the additional input of nutrients from marine ecosystems to terrestrial (Finney et al., 2002). On the Aleutian Islands, higher $\delta^{15} \mathrm{~N}$ values were found on islands where large seabirds colonies had survived, compared to islands where Arctic foxes had been introduced, which have subsequently reduced colonies in the past two centuries (Byrd, 1984; Croll et al., 2005; Maron et al., 2006). Thus, we can estimate the seabird impact dynamics on the coastal communities of Shemya Island by heavy nitrogen isotope evaluation.

Vegetation, as one of the components of ecosystems, is also affected by guano fertilization. A study of seabird colonies on the Pacific coast shows that even a short exposure of guano can lead to changes in the soil, plant communities, and chemical alterations in bedrock (Ellis, 2005; Ivanov, 2013). In the absence of human and terrestrial predators, birds can inhabit the entire island and form special ornithogenic ecosystems. Under the bird colonies pressure, peat soils have lower ash content and are enriched with nitrogen and phosphorus (Pleshchenko, 1992). LOI (average 75\%) and $\delta 15 \mathrm{~N}$ (average 13.7\%) in the McDonald Point peat deposit, which differ from the previous values, indicate this impact. This could also lead to changes in the vegetation cover. In general, studies point out a high mosaicity of vegetation and a noticeable change in the dominant species under the influence of bird colonies (Breslina, 1987; Garroutte et al., 2018; Ivanov, 2013). Therefore, we suppose that the input of additional organic matter led to the gradual formation of meadow vegetation on the coast of Shemya Island (Figure 3). According to Breslina (1987), Apiaceae, and Poaceae taxa are typical in the vicinity of bird colonies in the White Sea Islands. To the west of the Aleutians, in the Commander Islands, crowberry gradually decreased following the appearance of bird colonies (Mochalova, 2008) as well as in the McDonald Point pollen spectra (Figure 3). Grasses are significant members of ornithogenic communities (Mochalova, 2008). Calamagrostis purpurea and Leymus mollis are typical for coastal meadows, but due to avian impact, they grow higher on the slopes and occupy greater areas together with umbelliferous species (Mochalova, 2008). It is important to note that there are no specific species on the Aleutian Islands that would reflect only ornithogenic vegetation, since the islands have impoverished flora due to their remoteness and the considerable length of the archipelago (Garroutte \& Ickert-Bond, 2013; Hulten, 1968; Maron et al., 2006; Mochalova, 2008). We nevertheless found higher diversity of nonarboreal in the pollen spectra during this time (see Data
Availability Statement). Pollen influx in McDonald Point deposit also increased (Figures 3 and 4).

Cooling after the Holocene temperature maximum (Kaufman et al., 2016) may have led to a noticeable increase in the productivity of the Bering Sea (Anderson et al., 2005) and, as a consequence, an expansion of seabird colonies. Similar processes took place, for example, in the Greenland region, where the dynamics of the colony was also studied using $\delta 15 \mathrm{~N}$ (Davidson et al., 2018). However, on no other Aleutian Islands during the Holocene such pollen spectra and traces of the prolonged influence of seabird colonies were found due to the selection of peat deposits in the interior of the islands. Substantial increases in heavy nitrogen (up to 9.32 and $11.40 \%$ ) were found in a peat core on Carlisle Island (Islands of Four Mountains, Aleutian Islands) located in the eastern part of the archipelago (Kuzmicheva et al., 2019). But the peaks lasted within a few decades (the multiproxy resolution allows us to state this) circa 7,000 years ago, and then $\delta 15 \mathrm{~N}$ decreased and remained on average about 3\%o for almost 5,000 years. There were some increases in the relative abundance of Apiaceae and Poaceae at this time; however, there were no noticeable changes in vegetation (Kuzmicheva et al., 2019). At the same time, there was a shift of plant communities toward drier tundra in the interior of Shemya Island circa 4,700 cal year BP, while $\delta 15 \mathrm{~N}$ remained here on average 1.5\% (Savinetsy et al., 2014; Smyshlyaeva et al., 2021). Thus, with the long and strong influence of seabird colonies, significant changes in vegetation occurred, which affected only the coast of Shemya Island.

Circa 3,000 cal year BP the relative abundance of Apiaceae gradually began to decrease, while Poaceae percentage increased in the McDonald Point peat deposit (Figure 3). Dominance of these taxa is typical for modern ornithogenic vegetation on the Commander Islands, where grasses and umbelliferous are predominant around the seabird colonies (Mochalova, 2008). Peat remained uniform in density and LOI was consistently high (Figures 3 and 4); thus, the plant communities remained productive. Between 4,000 and 3,000 years ago, the Neoglacial commenced gradually without a pronounced pattern in the region (Barclay et al., 2009; Harada et al., 2014; Kaufman et al., 2016; Peteet et al., 2019). This climatic event was associated with a decrease in temperatures, high ice cover in the Bering Sea, and an intensification of winter-spring storms (Bailey et al., 2018; Harada et al., 2014; Kaufman et al., 2016; Majewski et al., 2004). More severe conditions have resulted in the gradual spread of grass-meadows in the place of herb-meadows on Shemya Island (Figures 3 and 4). Vegetation changes occurred around this time on Attu, Adak, and Umnak, where drier tundra spread (Heusser, 1973, 1978, 1990; Noguchi et al., 2018). Changes in plant communities are also associated with climate in other islands, for example on the Kodiak Island (Peteet et al., 2019), Ireland (Birks \& Peglar, 1979; Molloy \& O'Connell, 2004), the Kuril Islands (Razjigaeva et al., 2013), the Shetland Islands (Hulme \& Shirriffs, 1994), and the Faroe Islands (Lawson et al., 2008).

However, the decline of $\delta^{15} \mathrm{~N}$ also began about 3,000 cal year BP. For nearly 600 years, the value decreased from 14.0 to $9.0 \%$ (Figures 3 and 4). This was still several times higher than the $\delta^{15} \mathrm{~N}$ 
median value of the entire peatland (Savinetsky et al., 2014). Grass meadows with forbs dominated on the Shemya coast between 3,000 and 2,400 cal year BP, but the abundance of ornithogenic vegetation gradually decreased (Figure 3). Pollen influx remained relatively high (Figure 4). Savinetsky et al. (2014) suggested that the migration of humans to Shemya reduced the number of colonial birds which resulted in a decline in guano and, accordingly, $\delta^{15} \mathrm{~N}$. Circa 3,000 years ago, at least one settlement existed on the island, and by 2,000 years ago, there were three additional sites, according to archaeological evidence (Corbett \& Loring, 2010). The hypothesis of hunting is supported by numerous bird remains identified in these archaeological sites (Lefevre et al., 2010). There were no sufficiently protected habitats on island which could allow a large seabird colony to survive due to flat and low topography of Shemya (Savinetsky et al., 2014). The gradual decline in the colony population as a result of hunting led to a decrease in avian influence on vegetation over time. Anthropogenic settlement notably influenced the vegetation of other oceanic islands (Bennett et al., 1997; Hannon \& Bradshaw, 2000; Roy et al., 2018). Strongly pronounced ornithogenic vegetation formation probably did not form on Carlisle Island due to the fact that humans colonized the eastern part of the Bering Sea earlier and also began to reduce seabird colonies around 7,000 years ago (Kuzmicheva et al., 2019). In this case, we argue that, even without domesticated animals or agriculture in the Aleutian Islands, humans could significantly alter ecosystems during the Holocene.

An alternative hypothesis is that the climate influenced seabird population dynamics, which subsequently led to changes in vegetation. Similar impacts have been observed in different regions, including the Atlantic coast of Canada (Diamond \& Devlin, 2003), the Bering (Springer et al., 2007), and the Okhotsk seas (Andreev et al., 2005). Avian reproductive success can depend on the oceanic climate on the decadal scale (Bond, 2011). Additionally, avian reproductive success is influenced by the temperature in the winterspring period, which was altered during the Neoglacial (Harada et al., 2014; Sydeman et al., 2017).

Forb-grass meadows were abruptly replaced by sedge tundra circa 2,400 cal year BP (Figure 3). Peat did not change outwardly; however, LOI began to fluctuate sharply decreased, and pollen influx also became lower on average (Figure 3). On the coast of Shemya Island, the vegetation did not shift back exactly to dwarf shrub tundra, as it was described for ornithogenic vegetation on other islands with reduced seabird colonies (Breslina, 1987; Ivanov, 2013). On treeless islands, dwarf shrub communities are the final stages of the ecological succession series (Breslina, 1965). Similar communities have been noted on the Kamchatka and Sakhalin Peninsulas (Breslina, 1965). On North Pacific islands, near areas abandoned by seabird colonies more than 10 years ago, tundra with the Empetrum dominance formed, thus completing the cycle of vegetation restoration (Ivanov, 2013). Nevertheless, tundra replaced meadows on the Shemya coast, as in studies of modern vegetation in other Aleutian Islands, where the number of birds decreased after the introduction of foxes (Maron et al., 2006). The interior part of the island was not affected by the seabird guano, and, on the contrary, there was a shift to low-lying dwarf shrub tundra circa 3,600 cal year BP (Smyshlyaeva et al., 2021). Probably, the long-term nutrients input by avians in the oceanic island environment may continue to influence coastal vegetation even after the reduction of colonies.

From 2,400 cal year BP until recently, $\delta 15 \mathrm{~N}$ averaged $2.76 \%$ in the McDonald Point peat deposit (Savinetsky et al., 2014). This corresponds to the values at the Arctic and Subarctic peatlands (Davidson et al., 2018; Yuan et al., 2010), soils of the Aleutian Islands with introduced foxes (Maron et al., 2006), and is slightly higher than in the peat in the Shemya interior, where during the same time the average was $0.81 \%$ (Savinetsky et al., 2014). The most observable shifts in the coastal pollen spectra occurred when $\delta 15 \mathrm{~N}$ values passed through 9-10\% with the presence of a pronounced trend (Savinetsky et al., 2014). If the increase continued, Apiaceae and grasses began to predominate in plant communities, and a decrease in $\delta 15 \mathrm{~N}$ led to a transition to less productive vegetation (Figures 3 and 4). Moreover, the changes in the heavy nitrogen isotope content had to be long-term in order to be reflected in the pollen spectra. On Carlisle Island, for example, $\delta 15 \mathrm{~N}$ was rising above $9-10 \%$ when bird colonies returned to the island after major eruptions, but both of these increases lasted no more than 100-200 years and had insignificant impact on vegetation (Kuzmicheva et al., 2019). There plant communities also did not return to dwarf shrubs predominance after the decrease in fertilization, as in Shemya. Apparently, the vegetation on the Aleutian Islands after the reduction of seabird colonies, become less productive, but this is not always a shift from productive grasslands to low-lying dwarf shrubs communities.

Volcanic eruptions also played a significant role in the Aleutian Islands vegetation history (Heusser, 1990; Kuzmicheva et al., 2019; Talbot, Talbot, et al., 2010). Ash falls of various intensities could lead to the complete destruction of island landscape, a change in vegetation dominants, various disturbances of whole plants or their parts, a change in productivity or biomass, or have no effect (Heusser, 1990; Kuzmicheva et al., 2019; Talbot, Schofield, et al., 2010). However, on Shemya Island volcanism did not significantly affect the vegetation as the nearest volcanoes which were active in the Holocene are located 100-200 km to the east (Corbett et al., 2010; Miller et al., 1998); furthermore, there are no ash layers in soil and peat deposits on this island (Kiseleva et al., 2002).

\section{5 | CONCLUSIONS}

Despite the high bird population in the Aleutian Islands, the impact of guano has not been studied in the long term. In order to study the influence of seabird colonies on vegetation, we carried out a pollen analysis of a coastal peat deposit from Shemya Island. About 9,100 cal year BP, coastal vegetation was more or less stable. Sedge-heather tundra spread. The noticeable influence of seabird colonies increased 4,600 cal year BP, when the role of ornithogenic indicator taxa in the pollen spectra dramatically rose. Meadows, instead of tundra, spread out on the coast. Circa 3,000 cal year $\mathrm{BP}$, the bird colonies and their influence on the plant communities 
declined, due either to the settlement of the island by people who hunted birds or to climate change in the region, including a decrease in average temperatures and increased storminess in spring and winter. The vegetation remains ornithogenic; umbelliferous and grasses dominate in it. Shifts in atmospheric patterns could affect vegetation both directly and indirectly through their impact on bird populations. After a decrease $\delta 15 \mathrm{~N}$ below $9 \% 2,400$ cal year BP, the vegetation is replaced by a less productive sedge tundra. This habitat was exposed, but dwarf shrub tundra does not spread on it even after thousand years, as was found on some other Aleutian Islands, where the pressure of the avian influence decreased during the centuries. It is already clear that guano is one of the leading factors in the vegetation formation on the North Pacific islands; however, more studies with better resolution are needed on the other Aleutian Islands to distinguish the key $\delta 15 \mathrm{~N}$ values which were leading to marked changes in island ecosystems and spatial resolution of this process.

\section{ACKNOWLEDGMENTS}

The reported study was funded by Russian Foundation for Basic Research \#19-34-90071, National Geographic Society (\#4943-92, \#5252-94), National Science Foundation (OPP-93 14472) and supplementary grant from National Science Foundation (OPP-96 14472). We thank the Institut Français pour la Recherche et la Technologie Polaires (Program 30-1), with support from the United State Fish and Wildlife Service, The Aleut Corporation, and the Museum National d' Histoire Naturelle in Paris.

\section{CONFLICT OF INTEREST}

None declared.

\section{AUTHOR CONTRIBUTIONS}

Olesya I. Smyshlyaeva: Visualization (lead); Writing-original draft (lead); Writing-review \& editing (lead). Elena Erastovna Severova: Investigation (lead); Writing-review \& editing (equal). Olga Aleksandrovna Krylovich: Visualization (supporting); Writing-review \& editing (equal). Evgeniya Andreevna Kuzmicheva: Writing-review $\&$ editing (equal). Arkady Borisovich Savinetsky: Conceptualization (lead); Funding acquisition (equal); Supervision (lead); Writing-review \& editing (equal). West Dixie: Conceptualization (equal); Funding acquisition (equal); Writing-review \& editing (equal). Virginia Hatfield: Conceptualization (equal); Funding acquisition (equal); Writingreview \& editing (equal).

\section{DATA AVAILABILITY STATEMENT}

List of pollen samples; pollen count spreadsheet; pollen concentration spreadsheet; stable isotope, LOI and pollen influx results; complete pollen percentage and concentration diagrams: Dryad https:// doi.org/10.5061/dryad.Orxwdbs1f.

\section{ORCID}

Olesya Igorevna Smyshlyaeva iD https://orcid. org/0000-0001-6126-9167

\section{REFERENCES}

Anderson, L., Abbott, M. B., Finney, B. P., \& Burns, S. J. (2005). Regional atmospheric circulation change in the North Pacific during the Holocene inferred from lacustrine carbonate oxygen isotopes, Yukon Territory, Canada. Quaternary Research, 64(1), 21-35. https://doi.org/10.1016/j.yqres.2005.03.005

Anderson, P.M. (1988). Late Quaternary pollen records from the Kobukand Noatak River drainages, northwestern Alaska. Quaternary Research, 29(3), 263-276. https://doi.org/10.1016/0033-5894(88)90035-X

Anderson, S. T., \& Bank, T. P. (1952). Pollen and radiocarbon studies of Aleutian soil profiles. Science, 116(3004), 84-86. https://doi. org/10.1126/science.116.3004.84

Anderson, W. B., \& Polis, G. A. (1999). Nutrient fluxes from water to land: Seabirds affect plant nutrient status on Gulf of California islands. Oecologia, 118(3), 324-332. https://doi.org/10.1007/s0044 20050733

Andreev, A. V. (2005). Klyuchevye ornitologicheskie territorii bassejna Ohotskogo morya (Key bird areas of the Okhotsk Sea Basin). Vestnik Severo-Vostochnogo Nauchnogo Centra DVO RAN, 1, 57-77. https://www.elibrary.ru/item.asp?id=12515696

Bailey, H. L., Kaufman, D. S., Sloane, H. J., Hubbard, A. L., Henderson, A. C., Leng, M. J., Meyer, H., \& Welker, J. M. (2018). Holocene atmospheric circulation in the central North Pacific: A new terrestrial diatom and $\delta 180$ dataset from the Aleutian Islands. Quaternary Science Reviews, 194, 27-38. https://doi.org/10.1016/j.quasc irev.2018.06.027

Barclay, D. J., Wiles, G. C., \& Calkin, P. E. (2009). Holocene glacier fluctuations in Alaska. Quaternary Science Reviews, 28(21-22), 20342048. https://doi.org/10.1016/j.quascirev.2009.01.016

Bennett, K. D., Bunting, M. J., \& Fossitt, J. A. (1997). Long-term vegetation change in the Western and Northern Isles, Scotland. Botanical Journal of Scotland, 49(2), 127-140. https://doi.org/10.1080/03746 609708684861

Birks, H. J., \& Peglar, S. M. (1979). Interglacial pollen spectra from Sel Ayre. Shetland. New Phytologist, 83(2), 559-575. https://doi. org/10.1111/j.1469-8137.1979.tb07477.x

Black, R. F. (1980). Isostatic, tectonic, and eustatic movements of sea level in the Aleutian Islands, Alaska. In N.-A. Moerner (Ed.), Earth rheology, isostasy and eustacy (pp. 231-248). John Wiley \& Sons.

Bond, A. L., Jones, I. L., Sydeman, W. J., Major, H. L., Minobe, S., Williams, J. C., \& Byrd, G. V. (2011). Reproductive success of planktivorous seabirds in the North Pacific is related to ocean climate on decadal scales. Marine Ecology Progress Series, 424, 205-218. https://doi. org $/ 10.3354 /$ meps08975

Breslina, I. P. (1965). Sukcessionnye smeny na ostrovah arhipelaga Kandalakshskie shkhery (Beloe More) (Succession shifts on the islands of the Kandalaksha skerries archipelago (the White Sea)). Doklady Tskha, 113, 223-227.

Breslina, I. P. (1987). Rastenya i bodoplavayushchie pticy morskih ostrovov Kolskoy Subarktiki (Plants and waterfowl of the Kola Subarctic sea islands) (p. 1999). Nauka.

Broadman, E., Kaufman, D. S., Henderson, A. C., Berg, E. E., Anderson, R. S., Leng, M. J., Stahnke, S. A., \& Muñoz, S. E. (2020). Multi-proxy evidence for millennial-scale changes in North Pacific Holocene hydroclimate from the Kenai Peninsula lowlands, south-central Alaska. Quaternary Science Reviews, 241, 106420. https://doi. org/10.1016/j.quascirev.2020.106420

Brubaker, L. B., Garfinkel, H. L., \& Edwards, M. E. (1983). A late Wisconsin and Holocene vegetation history from the central Brooks Range: Implications for Alaskan palaeoecology. Quaternary Research, 20(2), 194-214. https://doi.org/10.1016/0033-5894(83)90077-7

Bunting, M. J. (1994). Vegetation history of Orkney, Scotland; pollen records from two small basins in west Mainland. New Phytologist, 128(4), 771-792. https://doi.org/10.1111/j.1469-8137.1994.tb040 $39 . x$ 
Byrd, G. V. (1984). Vascular vegetation of Buldir Island, Aleutian Islands, Alaska, compared to another Aleutian Island. Arctic, 37(1), 37-48. http://www.jstor.org/stable/40510241

Byrd, G. V., \& Day, R. H. (1986). The avifauna of Buldir Island, Aleutian Islands, Alaska. Arctic, 39(2), 109-118. http://www.jstor.org/stabl e/40510458

Causey, D., Corbett, T., \& Corbett, D. (2010). Chapter 7: The Biology and Ecology of Shemya Island. In D. Corbett, D. West, \& C. Lefevre (Eds.), The People at the End of the World: The Western Aleutians Project and the Archaeology of Shemya Island (pp. 83-92).AURORA (Alaska Anthropological Association Monograph Series - VIII).

Caut, S., Angulo, E., Pisanu, B., Ruffino, L., Faulquier, L., Lorvelec, O., Chapuis, J.-L., Pascal, M., Vidal, E., \& Courchamp, F. (2012). Seabird modulations of isotopic nitrogen on islands. PLoS One, 7(6), e39125. https://doi.org/10.1371/journal.pone.0039125

Chambers, F. M., Beilman, D. W., \& Yu, Z. (2010/2011). Methods for determining peat humification and for quantifying peat bulk density, organic matter and carbon content for palaeostudies of climate and peatland carbon dynamics. Mires and Peat, 7, 1-10. http://pixelrausc hen.de/wbmp/media/map07/map_07_07.pdf

Chambers, F. M., van Geel, B., \& van der Linden, M. (2011). Considerations for the preparation of peat samples for palynology, and for counting of pollen and non-pollen palynomorphs. Mires and Peat, 7(11), 114. https://www.researchgate.net/publication/228827211_Consi derations_for_the_preparation_of_peat_samples_for_palynology_ and_for_the_counting_of_pollen_and_non-pollen_palynomorphs

Charman, D. J. (1994). Late-glacial and Holocene vegetation history of the Flow Country, northern Scotland. New Phytologist, 127(1), 155-168. https://doi.org/10.1111/ j.1469-8137.1994.tb04270.x

Corbett, D. G., \& Loring, S. (2010). Chapter 10: Shemya Island Site Descriptions. In D. Corbett, D. West, \& C. Lefevre (Eds.), The People at the End of the World: The Western Aleutians Project and the Archaeology of Shemya Island (pp. 107-132). AURORA: (Alaska Anthropological Association Monograph Series - VIII).

Corbett, D., West, D., \& Lefevre, C. (2010). Chapter 1: History of the Western Aleutians Archaeological and Paleobiological Project. In D. Corbett, D. West, \& C. Lefevre (Eds.), The People at the End of the World: The Western Aleutians Project and the Archaeology of Shemya Island (pp. 1-16).AURORA (Alaska Anthropological Association Monograph Series - VIII).

Crockford, S. J. (2012). Chapter 6: Archaeozoology of Adak Island: 6000 years of subsistence history in the central Aleutians. The People Before: The Geology, Paleoecology and Archaeology of Adak Island, Alaska. Oxford. Archaeopress, British Archaeological Reports International Series, 2322, 107-143.

Croll, D. A., Maron, J. L., Estes, J. A., Danner, E. M., \& Byrd, G. V. (2005). Introduced predators transform subarctic islands from grassland to tundra. Science, 307(5717), 1959-1961. https://doi.org/10.1126/ science. 1108485

Davidson, T. A., Wetterich, S., Johansen, K. L., Grønnow, B., Windirsch, T., Jeppesen, E., Syväranta, J., Olsen, J., González-Bergonzoni, I., Strunk, A., Larsen, N. K., Meyer, H., Søndergaard, J., Dietz, R., Eulears, I., \& Mosbech, A. (2018). The history of seabird colonies and the North Water ecosystem: Contributions from palaeoecological and archaeological evidence. Ambio, 47(2), 175-192. https:// doi.org/10.1007/s13280-018-1031-1

Diamond, A. W., \& Devlin, C. M. (2003). Seabirds as indicators of changes in marine ecosystems: Ecological monitoring on Machias Seal Island. Environmental Monitoring and Assessment, 88(1), 153-181. https://doi.org/10.1023/A:1025560805788

Eisner, W. R., Bockheim, J. G., Hinkel, K. M., Brown, T. A., Nelson, F. E., Peterson, K. M., \& Jones, B. M. (2005). Paleoenvironmental analyses of an organic deposit from an erosional landscape remnant, Arctic Coastal Plain of Alaska. Palaeogeography, Palaeoclimatology,
Palaeoecology, 217(3-4), 187-204. https://doi.org/10.1016/j. palaeo.2004.11.025

Ellis, J. C. (2005). Marine birds on land: A review of plant biomass, species richness, and community composition in seabird colonies. Plant Ecology, 181(2), 227-241. https://doi.org/10.1007/s1125 8-005-7147-y

Faegri, K., \& Iversen, J. (1975). Textbook of pollen analysis (p. 328). Munksgaard.

Finney, B. P., Gregory-Eaves, I., Douglas, M. S. V., \& Smol, J. P. (2002). Fisheries productivity in the northeastern Pacific Ocean over the past 2,200 years. Nature, 416(6882), 729-733. https://doi. org/10.1038/416729a

Gałka, M., Swindles, G. T., Szal, M., Fulweber, R., \& Feurdean, A. (2018). Response of plant communities to climate change during the late Holocene: Palaeoecological insights from peatlands in the Alaskan Arctic. Ecological Indicators, 85, 525-536. https://doi.org/10.1016/j. ecolind.2017.10.062

Garroutte, M., Huettmann, F., Webb, C. O., \& Ickert-Bond, S. M. (2018). Biogeographic and anthropogenic correlates of Aleutian Islands plant diversity: A machine-learning approach. Journal of Systematics and Evolution, 56(5), 476-497. https://doi.org/10.1111/jse.12456

Garroutte, M. D., \& Ickert-Bond, S. M. (2013). Origins of varied floristic compositions in the western Aleutian and Northern Bering Sea Islands. Alaska Park Science, 12(1), 70-79. https://www.researchga te.net/profile/Stefanie-Ickert-Bond/publication/260166168_Origi ns_of_varied_floristic_compositions_in_the_Western_Aleutian_ and_Northern_Bering_Sea_islands/links/Of31752fdb900c64bc00 0000/Origins-of-varied-floristic-compositions-in-the-WesternAleutian-and-Northern-Bering-Sea-islands.pdf

Gąsiorowski, M., \& Sienkiewicz, E. (2019). Bird population changes reconstructed from isotopic signals of peat developed in a nutrient enriched tundra. Science of the Total Environment, 646, 1359-1366. https://doi.org/10.1016/j.scitotenv.2018.07.453

Grimm, E. C. (2015). Tilia (software). Version, 2, 41. https://www.tilia it.com/download/

Hannon, G. E., \& Bradshaw, R. H. (2000). Impacts and timing of the first human settlement on vegetation of the Faroe Islands. Quaternary Research, 54(3), 404-413. https://doi.org/10.1006/qres.2000.2171

Harada, N., Katsuki, K., Nakagawa, M., Matsumoto, A., Seki, O., Addison, J. A., Finney, B. T., \& Sato, M. (2014). Holocene sea surface temperature and sea ice extent in the Okhotsk and Bering Seas. Progress in Oceanography, 126, 242-253. https://doi.org/10.1016/j. pocean.2014.04.017

Haslett, J., \& Parnell, A. (2008). A simple monotone process with application to radiocarbon-dated depth chronologies. Journal of the Royal Statistical Society: Series C (Applied Statistics), 57(4), 399-418. https://doi.org/10.1111/j.1467-9876.2008.00623.x

Heusser, C. J. (1973). Postglacial vegetation on Umnak Island, Aleutian Islands, Alaska. Review of Palaeobotany and Palynology, 15(4), 277285. https://doi.org/10.1016/0034-6667(73)90033-X

Heusser, C. J. (1978). Postglacial vegetation on Adak Island, Aleutian Islands, Alaska. Bulletin of the Torrey Botanical Club, 105(1), 18-23. https://doi.org/10.2307/2484259

Heusser, C. J. (1983). Pollen diagrams from the Shumagin Islands and adjacent Alaska Peninsula, southwestern Alaska. Borea, 12(4), 279295. https://doi.org/10.1111/j.1502-3885.1983.tb00322.x

Heusser, C. J. (1990). Late Quaternary vegetation of the Aleutian Islands, southwestern Alaska. Canadian Journal of Botany, 68(6), 13201326. https://doi.org/10.1139/b90-168

Hicks, S., \& Hyvärinen, H. (1999). Pollen influx values measured in different sedimentary environments and their palaeoecological implications. Grana, 38(4), 228-242. https://doi.org/10.1080/0017313007 50044618

Hulme, P. D., \& Shirriffs, J. (1994). The Late-glacial and Holocene vegetation of the Lang Lochs Mire area, Gulberwick, Shetland: A pollen 
and macrofossil investigation. New Phytologist, 128(4), 793-806. https://doi.org/10.1111/j.1469-8137.1994.tb04040.x

Hultén, E. (1937). Outline of the history of arctic and boreal biota during the Quaternary period. J. Cramer.

Hultén, E. (1968). Flora of Alaska and neighboring territories: A manual of the vascular plants, Vol. 2193. Stanford University Press.

Ivanov, A. N. (2013). Ornitogennye geosistemy ostrovov Severnoy Pacifiki (Ornithogenic geosystems of the North Pacific islands) (p. 228). Nauchnyj mir.

Janbu, A. D., Paasche, Ø., \& Talbot, M. R. (2011). Paleoclimate changes inferred from stable isotopes and magnetic properties of organic-rich lake sediments in Arctic Norway. Journal of Paleolimnology, 46(1), 29-44. https://doi.org/10.1007/s10933-011-9512-2

Jordan, J. W., \& Krumhardt, A. (2003). Postglacial climate and vegetation on the western Alaska Peninsula. Alaska Journal Anthropology, 1, 16-33.

Kaufman, D. S., Axford, Y. L., Henderson, A. C., McKay, N. P., Oswald, W. W., Saenger, C., Anderson, R. S., Bailey, H. L., Clegg, B., Gajewski, K., Hu, F. S., Jones, M. C., Massa, C., Routson, C. C., Werner, A., Wooller, M. J., \& Yu, Z. (2016). Holocene climate changes in eastern Beringia (NW North America)-A systematic review of multi-proxy evidence. Quaternary Science Reviews, 147, 312-339. https://doi. org/10.1016/j.quascirev.2015.10.021

Kiseleva, N. K., Savinetsky, A. B., \& Khasanov, B. F. (2002). Pazvitie prirodnyh processov na o. Shemya $v$ golocene (Development of natural processes on Shemya Island in the Holocene). Izvestya RAN Serya Geograficheskaya, 1, 97.

Krylovich, O. A., Vasyukov, D. D., Khasanov, B. F., Hatfield, V., West, D., \& Savinetsky, A. A. (2019). Hunter-gatherers subsistence and impact on fauna in the Islands of Four Mountains, Eastern Aleutians, Alaska, over 3000 yr. Quaternary Research, 91(3), 983-1002. https://doi.org/10.1017/qua.2018.127

Kuzmicheva, E. A., Smyshlyaeva, O. I., Vasyukov, D. D., Khasanov, B. F., Krylovich, O. A., Okuno, M., West, D. L., Hatfield, V. L., \& Savinetsky, A. B. (2019). A 7300-yr-old environmental history of seabird, human, and volcano impacts on Carlisle Island (the Islands of Four Mountains, eastern Aleutians, Alaska). Quaternary Research, 91(3), 934-952. https://doi.org/10.1017/qua.2018.114

Lawson, I. T., Church, M. J., McGovern, T. H., Arge, S. V., Woollet, J., Edwards, K. J., Gathorne-Hardy, F. J., Dugmore, A. J., Cook, G., Mairs, K. A., Thomson, A. M., \& Sveinbjarnardótti, G. (2005). Historical ecology on Sandoy, Faroe Islands: Palaeoenvironmental and archaeological perspectives. Human Ecology, 33(5), 651-684. https://www.jstor.org/stable/4603594

Lawson, I. T., Edwards, K. J., Church, M. J., Newton, A. J., Cook, G. T., Gathorne-Hardy, F. J., \& Dugmore, A. J. (2008). Human impact on an island ecosystem: Pollen data from Sandoy, Faroe Islands. Journal of Biogeography, 35(6), 1130-1152. https://doi. org/10.1111/j.1365-2699.2007.01838.x

Lefèvre, C., Corbett, D., Crockford, S., Czederpiltz, J., Partlow, M., \& West, D. (2010). Faunal remains and intersite comparisons. In D. Corbett, D. West \& C. Lefèvre (Eds.), The People at the end of the world: The Western Aleutian Project and Archaeology of Shemya Island (pp. 133-157). Aurora.

Maron, J. L., Estes, J. A., Croll, D. A., Danner, E. M., Elmendorf, S. C., \& Buckelew, S. L. (2006). An introduced predator alters Aleutian Island plant communities by thwarting nutrient subsidies. Ecological Monographs, 76(1), 3-24. https://doi. org/10.1890/05-0496

Mayewski, P. A., Rohling, E. E., Stager, J. C., Karlén, W., Maasch, K. A., Meeker, L. D., Meyerson, E. A., Gasse, F., van Kreveld, S., Holmgren, K., Lee-Thorp, J., Rosqvist, G., Rack, F., Staubwasser, M., Schneider, R. R., \& Steig, E. J. (2004). Holocene climate variability. Quaternary Research, 62(3), 243-255. https://doi.org/10.1016/j. yqres.2004.07.001
McCord, R. A. (1980). Biogeography of the vascular flora on islands in the Bering Sea region (p. 249). Ph.D. Dissertation. University of Tennessee.

Miller, T. P., McGimsey, R. G., Richter, D. H., Riehle, J. R., Nye, C. J., Yount, M. E., \& Dumoulin, J. A. (1998). Catalog of the historically active volcanoes of Alaska (p. 104). United States Department of the Interior, United States Geological Survey.

Mochalova, O. A. (2008). Rastitelnost v zoogennyh mestoobitaniyah na Komandorskih ostrovah (Vegetation in zoogenic habitats on the Commander Islands). Sibirskiy Ecologicheskiy Zhurnal, 2, 289-301.

Molloy, K., \& O'Connell, M. (2004). Holocene vegetation and land-use dynamics in the karstic environment of Inis Oırr, Aran Islands, western Ireland: Pollen analytical evidence evaluated in light of the archaeological record. Quaternary International, 113(1), 41-64. https://doi.org/10.1016/S1040-6182(03)00079-X

Neplukhina, A. A., Chudaev, D. A., Krylovich, O. A., \& Gololobova, M. A. (2018). Diatoms of the peatbog sediments from Shemya Island (Aleutian Islands, United States). Moscow University Biological Science Bulletin, 73(2), 76-81. https://doi.org/10.3103/S0096 392518020074

Noguchi, M., Fujiki, T., Okuno, M., Gualtieri, L., Hatfield, V., Sarata, B., Torii, M., Wada, K., Nakamura, T., \& West, D. (2018). Vegetation Changes around Haven Lake, Adak Island, Central Aleutians, Alaska, determined from pollen analysis. Radiocarbon, 60(5), 14831492. https://doi.org/10.1017/RDC.2018.103

Parnell, A. B.. (2015) Radiocarbon dating, age-depth modelling, relative sea level rate estimation, and non-parametric phase modelling. $\mathrm{R}$ package version 4.1. 1. https://cran.r-project.org/web/packages/Bchron/ index.html

Perren, B. B., Wolfe, A. P., Cooke, C. A., Kjaer, K. H., Mazzucchi, D., \& Steig, E. J. (2012). Twentieth-century warming revives the world's northernmost lake. Geology, 40(11), 1003-1006. https://doi. org/10.1130/G33621.1

Peteet, D. M., Nichols, J. E., \& Mann, D. H. (2019). Holocene Vegetation, Climate, and Carbon History on Western Kodiak Island. Alaska. Frontiers in Earth Science, 7, 61. https://doi.org/10.3389/ feart.2019.00061

Piotrowska, N., Blaauw, M., Mauquoy, D., \& Chambers, F. M. (2011). Constructing deposition chronologies for peat deposits using radiocarbon dating. Mires and Peat, 7(10), 1-14. http://pixelrauschen. de/wbmp/media/map07/map_07_10.pdf

Pleshchenko, S. V. (1992) Nekotorye osobennosti pochvoobrazovaniya $v$ mestah massovyh poselenij morskih kolonial'nyh ptic na ostrove Talan (Some features of soil formation on the colonial seabirds habitats on Talan Island). Pribrezhnye ekosistemy Severnogo Ohotomor'ya: ostrov Talan. Magadan: IBPS DVO RAN, 109-115.

$R$ Core Team (2019). R: A language and environment for statistical computing. R Foundation for Statistical Computing. https://www.R-proje ct.org/

Razjigaeva, N. G., Ganzey, L. A., Grebennikova, T. A., Belyanina, N. I., Mokhova, L. M., Arslanov, K. A., \& Chernov, S. B. (2013). Holocene climatic changes and vegetation development in the Kuril Islands. Quaternary International, 290, 126-138. https://doi.org/10.1016/j. quaint.2012.06.034

Reille, M. (1998). Pollen et Spores d'Europe et d'Afrique du Nord: Supplement 2 (p. 521). Marseille: Laboratoire de botanique historique et palynologie.

Reille, M. (1999). Pollen et spores d'Europe et d'Afrique du Nord: Index ( $\mathrm{p}$. 535). Marseille: Laboratoire de Botanique historique et Palynologie.

Reimer, P. J., Bard, E., Bayliss, A., Beck, J. W., Blackwell, P. G., Ramsey, C. B., Buck, C. E., Cheng, H., Edwards, R. L., Friedrich, M., Grootes, P. M., Guilderson, T. P., Haflidason, H., Hajdas, I., Hatte, C., Heaton, T. J., Hoffmann, D. L., Hogg, A. G., Hughen, K. A., ... Van Der Plicht, J. (2013). IntCal13 and Marine13 radiocarbon age calibration curves 0-50,000 years cal BP. Radiocarbon, 55(4), 1869-1887. https://doi. org/10.2458/azu_js_rc. 55.16947 
Rodionov, S. N., Bond, N. A., \& Overland, J. E. (2007). The Aleutian Low, storm tracks, and winter climate variability in the Bering Sea. Deep Sea Research Part II: Topical Studies in Oceanography, 54(23-26), 2560-2577. https://doi.org/10.1016/j.dsr2.2007.08.002

Rodionov, S. N., Overland, J. E., \& Bond, N. A. (2005). Spatial and temporal variability of the Aleutian climate. Fisheries Oceanography, 14 3-21. https://doi.org/10.1111/j.1365-2419.2005.00363.x

Roy, N., Bhiry, N., Woollett, J., \& Fréchette, B. (2018). Vegetation history since the mid-Holocene in northeastern Iceland. Ecoscience, 25(2), 109-123. https://doi.org/10.1080/11956860.2018.1443419

Savinetsky, A. B., Khasanov, B. F., West, D. L., Kiseleva, N. K., \& Krylovich, O. A. (2014). Nitrogen isotope composition of peat samples as a proxy for determining human colonization of islands. Arctic Anthropology, 51(1), 78-85. https://doi.org/10.3368/aa.51.1.78

Savinetsky, A. B., Kiseleva, N. K., Khassanov, B. F., Lefevre, C., \& Corbett, D. (2010). Chapter 6: Paleoenvironment-Holocene deposits from Shemya Island. In D. Corbett, D. West, \& C. Lefevre (Eds.), The People at the End of the World: The Western Aleutians Project and the Archaeology of Shemya Island (pp. 71-82).AURORA (Alaska Anthropological Association Monograph Series - VIII).

Severova, E. E., Nilova, M. V., Devyatov, A. G., Volkova, O. A., Polevova, S. V., Platonova, A. G., Rudko, A. I., Filin, V. R., \& Firnin, D. M. (2016). Open information system on plant anatomy and morphology for identification of botanical objects. Byulleten'moskovskogo Obshchestva Ispytatelei Prirody Otdel Biologicheskii, 121(5), 81-82.

Smyshlyaeva, O. I., Severova, E. E., Khasanov, B. F., Krylovich, O. A., Kuzmicheva, E. A., \& Savinetsky, A. B. (2021). The Near Islands (The Aleutian Arc) vegetation history in the Holocene. Biology Bulletin, 4, 389-398. https://doi.org/10.1134/S1062359021040130

Springer, A. M., Byrd, G. V., \& Iverson, S. J. (2007). Hot oceanography: Planktivorous seabirds reveal ecosystem responses to warming of the Bering Sea. Marine Ecology Progress Series, 352, 289-297. https://doi.org/10.3354/meps07080

Stockmarr, J. (1973). Determination of spore concentration with an electronic particle counter. Geological Survey of Denmark Yearbook, 1972, 87-89.

Sydeman, W. J., Thompson, S. A., Piatt, J. F., García-Reyes, M., Zador, S., Williams, J. C., Romano, M., \& Renner, H. M. (2017). Regionalizing indicators for marine ecosystems: Bering Sea-Aleutian Island seabirds, climate, and competitors. Ecological Indicators, 78, 458-469. https://doi.org/10.1016/j.ecolind.2017.03.013
Szpak, P., Longstaffe, F. J., Millaire, J. F., \& White, C. D. (2012). Stable isotope biogeochemistry of seabird guano fertilization: Results from growth chamber studies with Maize (Zea mays). PLoS One, 7(3), e33741.

Talbot, S. S., Schofield, W. B., Talbot, S. L., \& Daniëls, F. J. (2010) Vegetation of eastern Unalaska Island, Aleutian Islands, Alaska. Botany-Botanique, 88(4), 366-388. https://doi.org/10.1139/ B09-113

Talbot, S. S., \& Talbot, S. L. (1994). Numerical classification of the coastal vegetation of Attu Island, Aleutian Islands, Alaska. Journal of Vegetation Science, 5(6), 867-876. https://doi.org/10.2307/3236199

Talbot, S. S., Talbot, S. L., \& Walker, L. R. (2010). Post-eruption legacy effects and their implications for long-term recovery of the vegetation on Kasatochi Island, Alaska. Arctic, Antarctic, and Alpine Research, 42(3), 285-296. https://doi.org/10.1657/1938-4246-42.3.285

Weigelt, P., Steinbauer, M. J., Cabral, J. S., \& Kreft, H. (2016). Late Quaternary climate change shapes island biodiversity. Nature, 532(7597), 99-102. https://doi.org/10.1038/nature17443

West, D., Crawford, M., \& Savinetsky, A. B. (2007). Genetics, prehistory and the colonisation of the Aleutian Islands. Earth and Environmental Science Transactions of the Royal Society of Edinburgh, 98(1), 47-57. https://doi.org/10.1017/S1755691007000023

Yuan, L., Sun, L., Long, N., Xie, Z., Wang, Y., \& Liu, X. (2010). Seabirds colonized Ny-Ålesund, Svalbard, Arctic 9,400 years ago. Polar Biology, 33(5), 683-691. https://doi.org/10.1007/s00300-009-0745-8

How to cite this article: Smyshlyaeva, O. I., Severova, E. E., Krylovich, O. A., Kuzmicheva, E. A., Savinetsky, A. B., Dixie, W., \& Hatfield, V. (2021). Ornithogenic vegetation: How significant has the seabird influence been on the Aleutian Island vegetation during the Holocene? Ecology and Evolution, 11, 14088-14100. https://doi.org/10.1002/ece3.8121 